\title{
Cenomanian-Turonian transition in a shallow water sequence of the Sinai, Egypt
}

\author{
B. Gertsch · G. Keller $\cdot$ T. Adatte • \\ Z. Berner - A. S. Kassab - A. A. A. Tantawy · \\ A. M. El-Sabbagh $\cdot$ D. Stueben
}

Received: 25 July 2007/ Accepted: 27 September 2008

(C) Springer-Verlag 2008

\begin{abstract}
Environmental and depositional changes across the Late Cenomanian oceanic anoxic event (OAE2) in the Sinai, Egypt, are examined based on biostratigraphy, mineralogy, $\delta^{13} \mathrm{C}$ values and phosphorus analyses. Comparison with the Pueblo, Colorado, stratotype section reveals the Whadi El Ghaib section as stratigraphically complete across the late Cenomanian-early Turonian. Foraminifera are dominated by high-stress planktic and benthic assemblages characterized by low diversity, lowoxygen and low-salinity tolerant species, which mark shallow-water oceanic dysoxic conditions during OAE2. Oyster biostromes suggest deposition occurred in less than $50 \mathrm{~m}$ depths in low-oxygen, brackish, and nutrient-rich waters. Their demise prior to the peak $\delta^{13} \mathrm{C}$ excursion is
\end{abstract}

B. Gertsch $(\bowtie) \cdot$ G. Keller

Department of Geosciences,

Princeton University, Princeton, NJ 08544, USA

e-mail: bgertsch@princeton.edu

T. Adatte

Institut de géologie et paleontology, Université de Lausanne,

Anthropole, 1015 Lausanne, Switzerland

Z. Berner · D. Stueben

Institute for Mineralogy and Geochemistry,

University of Karlsruhe, 76128 Karlsruhe, Germany

\section{A. S. Kassab}

Department of Geology, Faculty of Science,

Assiut University, Assiut 71516, Egypt

A. A. A. Tantawy

Department of Geology, South Valley University,

Aswan 81528, Egypt

A. M. El-Sabbagh

Department of Geology, Faculty of Science,

Alexandria University, Alexandria 21526, Egypt likely due to a rising sea-level. Characteristic OAE2 anoxic conditions reached this coastal region only at the end of the $\delta^{13} \mathrm{C}$ plateau in deeper waters near the end of the Cenomanian. Increased phosphorus accumulations before and after the $\delta^{13} \mathrm{C}$ excursion suggest higher oxic conditions and increased detrital input. Bulk-rock and clay mineralogy indicate humid climate conditions, increased continental runoff and a rising sea up to the first $\delta^{13} \mathrm{C}$ peak. Above this interval, a dryer and seasonally well-contrasted climate with intermittently dry conditions prevailed. These results reveal the globally synchronous $\delta^{13} \mathrm{C}$ shift, but delayed effects of OAE2 dependent on water depth.

Keywords Cenomanian-Turonian - OAE 2 .

Paleoclimate $\cdot$ Shallow shelf environments $\cdot$ Egypt

\section{Introduction}

The late Cenomanian-early Turonian experienced major climatic and paleoceanographic changes, including greenhouse warming (Huber et al. 2002; Norris et al. 2002), a sea level transgression (Haq and Hardenbol 1987; Hallam 1992), global oceanic anoxia known as OAE2 (Arthur et al. 1988; Jenkyns 1980; Kolonic et al. 2005) and faunal and floral turnovers (Erbacher et al. 1996; Keller et al. 2001, 2008; Leckie et al. 2002; Erba and Tremolada 2004; Keller and Pardo 2004). Deposition of organic-rich black shale is the most evident expression of OAE2, particularly in deeper waters, upwelling areas and basin settings of the low latitude Tethys Ocean. Across the Tethys continental shelf, organic-rich sediment deposition was not uniform, but mainly occurred in deeper basins (e.g., Tunisia, Morocco), which have been studied extensively (e.g., Nederbragt and Fiorentino 1999; Kuhnt et al. 1997, 2004; 
Kolonic et al. 2002, 2005; Keller et al. 2008; Mort et al. 2007).

In organic-rich and carbonate sedimentary rocks of deeper environments, the Late Cenomanian OAE2 is generally characterized by a positive $2 \% \delta^{13} \mathrm{C}$ excursion consisting of two closely spaced peaks separated by a trough (e.g., Jarvis et al. 1988; Hart and Leary 1989; Paul et al. 1999; Keller et al. 2001, 2004; Tsikos et al. 2004). In contrast, dark organic-rich sediments are rare or absent in shallow marine platform and coastal areas, and the biotic and environmental effects of OAE2 are less well known. The rare studies dealing with Tethysian shallow-water environments during the late Cenomanian-early Turonian crisis reveal the demise of carbonate platforms and aragonite secreting rudists during the late Cenomanian (Philip and Airaud-Crumiere 1991). These ecological changes are mainly linked with the eustatic sea level rise characteristic of this period, together with high planktonic activity, anoxic or hypoxic waters and detritus input.

The Sinai in the eastern Tethys presents an ideal area to investigate the nature of OAE2 in coastal and inner shelf settings. During the Late Cretaceous, Egypt was part of a broad Tethyan Seaway (Fig. 1a) with open marine circulation to the Indo-Pacific in the east and the AtlanticCaribbean-Pacific to the west. Shallow seas covered continental regions in North Africa, Europe, the Middle East and the Ural region, and a warm climate, high marine productivity and rapid burial of organic matter resulted in dark organic-rich sediment deposition in basins and/or upwelling areas during OAE2 (Luning et al. 2004).

During the late Cenomanian-early Turonian, shallow inland seas in Egypt deposited limestones, marls, sands and oyster beds, which are exposed today in the Sinai. Most studies of the Cenomanian-Turonian (C-T) sequences of Egypt have concentrated on biostratigraphy and faunal turnovers based on macrofossils (ammonites) and microfossils (foraminifera, nannofossils), and very few dealt with the paleoclimatic, environmental and paleoceanographic changes (Kora and Hamama 1987; Cherief et al. 1989; Orabi 1992; Kassab and Ismael 1994; Kora et al. 1994; Kassab and Ismael 1996; Kassab 1999; Bauer et al. 2001; Kassab and Obaidalla 2001).

This study focuses on the environmental effects of OAE2 upon a shallow water coastal sequence in the Wadi El Ghaib of the Sinai, Egypt, and correlates these results with the Pueblo, Colorado, stratotype section and point (GSSP). The investigation is based on: (1) biostratigraphy to obtain age control and evaluate the biotic effects; (2) stable carbon isotopes to evaluate changes in productivity and the extend of the OAE2 $\delta^{13} \mathrm{C}$ excursion in marine-coastal areas; (3) sedimentology to identify facies and sea level changes; (4) clay and bulk-rock mineralogy to evaluate the paleoclimatic evolution and depositional environment; and (5) total

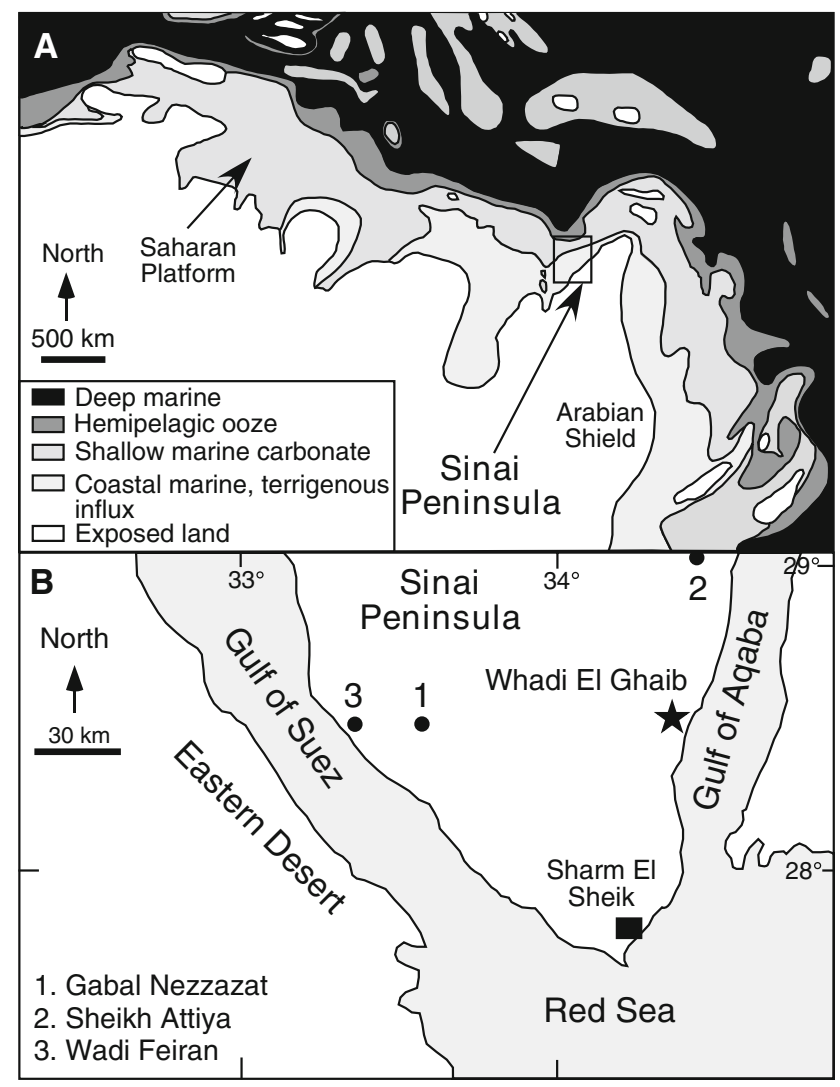

Fig. 1 a Late Cenomanian (94.7-93.5 Ma) paleogeographic map and depositional environments of the Peri-Tethyan domain (modified from Philip 2003). b Location of the Whadi El Ghaib and other Cenomanian-Turonian sequences (Gabal Nezzazat, Sheikh Attyia, Wadi Feiran) in the Sinai, Egypt

phosphorus quantification to test the hypothesis of decoupled carbon $(\mathrm{C})$ and phosphorus $(\mathrm{P})$ cycles during the $\mathrm{C}-\mathrm{T}$ transition in shallow water environments.

\section{Methods}

In the field, the Whadi El Ghaib section was examined for lithological changes, burrows and macrofossils, carefully described, measured and sampled. A total of 130 samples were collected at an average of $25 \mathrm{~cm}$ intervals. In the laboratory, samples were processed for foraminiferal analysis using standard methods (Keller et al. 2001). Species from each sample residue were picked and identified. Planktic foraminifera are generally rare. In samples with good foraminiferal assemblages, quantitative estimates of species abundances were obtained.

Carbon isotope analysis was performed on powdered bulk rock samples at the stable isotope laboratory at the University of Karlsruhe, Germany, using an Optima (Micromass, UK) ratio mass spectrometer equipped with an online carbonate preparation line (Multi Carb) with 
separate vials for each sample. The results were calibrated to the PDB scale with standard deviation of $0.05 \%$ for $\delta^{13} \mathrm{C}$ and of $0.1 \%$ for $\delta^{18} \mathrm{O}$.

Mineralogical and total phosphorus quantification analyses were carried out at the Geological Institute of the University of Neuchâtel, Switzerland. Bulk rock and clay mineral assemblages were analyzed by X-ray diffraction (Scintag XRD 2000 Diffractometer) based on procedures described by Kübler (1983) and Adatte et al. (1996). This method permits the semi-quantification of whole-rock mineralogy, obtained by XRD patterns of random powder samples by using external standards with an error varying between 5 and $10 \%$ for the phyllosilicates and $5 \%$ for grain minerals.

Clay mineralogical analysis is based on methods developed by Kübler (1987) and Adatte et al. (1996). The intensities of the identified minerals are measured for a semi-quantitative estimate of the proportion of clay minerals, which is therefore given in relative percent without correction factors.

Total phosphorus quantification analysis was performed on bulk rock samples, following the procedure described in Bodin et al. (2006). The concentration of $\mathrm{PO}_{4}$ in ppm is obtained by calibration with known standards solutions, using a photospectrometer (Perkin Elmer UV/Vis Photospectrometer Lambda 10). Phosphorus mass accumulation rates were not plotted because of the relative age control uncertainty of this shallow-water sequence.

\section{Geologic setting}

The Whadi El Ghaib section is located in the hills north of Sharm El Sheik in south central Sinai, Egypt $\left(34^{\circ} 29^{\prime}\right.$ E, $28^{\circ} 48^{\prime} \mathrm{N}$, Fig. 1b). Similar shallow water C-T sections are located to the east (Sheik Atiya) and along the Gulf of Suez (Wadi Feiran (Kora et al. 1994; Kassab and Obaidalla 2001) and Gabal Nezzazat (Cherief et al. 1989; AbdelGawat 1999; Fig. 1b). These C-T sections consist of shallow marine carbonates and siliciclastics, which change to coastal and terrestrial facies in the south of Egypt (Luning et al. 1998, 2004). The C-T sequences in the southern Sinai comprise three formations: the Raha (middle-late Cenomanian), the Abu Qada (late Cenomanian-middle Turonian) and the Wata Formations (middle-late Turonian) (Fig. 2). The Raha Formation (Ghorab 1961) consists of poorly fossiliferous calcareous sandstones with few bioturbated horizons rich in small oysters and trigonid bivalves. The Abu Qada Formation (Ghorab 1961) consists of marls, nodular marls, marly limestones, shales and oyster-rich limestone beds, with ammonites, gastropods, bivalves, echinoids, corals, and ichnofossils. The Wata Formation (Ghorab 1961) consists of marls, marly limestone, dolomitic limestone and nodular limestones with abundant ammonites of Turonian age.

In the proximal Whadi El Ghaib section, a clear distinction of the different formations is difficult, because their definition was established in more distal sequences. Therefore, the position of the boundary between the formations is based on the comparison with the Wadi Feiran ammonite biostratigraphy (Kassab and Obaidalla 2001).

\section{Lithology}

The C-T transition in the Wadi El Ghaib reflects a typical shallow nearshore environment deepening with the late Cenomanian-late Turonian sea level rise. Sediments in the lower $3 \mathrm{~m}$ of the section consist of bioturbated calcareous sandstones with glauconite (Figs. 2, 3a), followed by alternating oyster-rich limestones (Fig. 3b) and silty-sandy shale layers $(3-17 \mathrm{~m})$. Fossils are rare, including the ammonite Neobilites vibrayeanus (sample WG 24, Figs. 2, 3). A limestone bed marks the transition to fossiliferous marls with nodules (Fig. 3c), gastropods (Harpagodes, Strombus), echinoids and bivalves (Fig, 3d, 18-26 m). A marly limestone with gastropods $(26-27.1 \mathrm{~m})$ marks the transition to red laminated shale (27.1-28.6 m), marl with nodules and ammonites at the top (28.6-29.2 m), and red laminated shale with rare gastropods and echinoids (29.2$31.2 \mathrm{~m}$, Figs. 2, 3e-g). A red marly limestone with echinoids, nodules, glauconite and ammonites $(31.2-33 \mathrm{~m}$, Fig. 3h) underlies a thin layer of glauconitic shale (33$33.2 \mathrm{~m}$ ) and shale with only rare glauconite $(33.2-35 \mathrm{~m})$ (Fig. 3g). At the top of the section, shales and marls (35$38 \mathrm{~m}$ ) underlie a marly limestone bed (Figs. 2, 3g).

\section{Biostratigraphy and paleoenvironment}

Biostratigraphy of shallow water sequences is inherently difficult because of the generally low species diversity, sporadic microfossil occurrences and low diversity and endemism in macrofossils. These difficulties are also apparent in the Sinai sections. However, good age control can be obtained for the Cenomanian-Turonian transition by integrating macro- and microfossil biostratigraphies with carbon isotope stratigraphy. This method was applied at the Whadi El Ghaib section and the results correlated with the Pueblo, Colorado, stratotype section and point (GSSP, Fig. 4, Keller and Pardo 2004; Keller et al. 2004, Sageman et al. 2006).

\section{Macrofossil biostratigraphy}

The stratigraphy and macrofaunas of the CenomanianTuronian successions of the Sinai have been widely studied 




Fig. 2 Lithological description of the Whadi El Ghaib section and photos of the outcrop showing oyster beds and the Cenomanian-Turonian boundary 

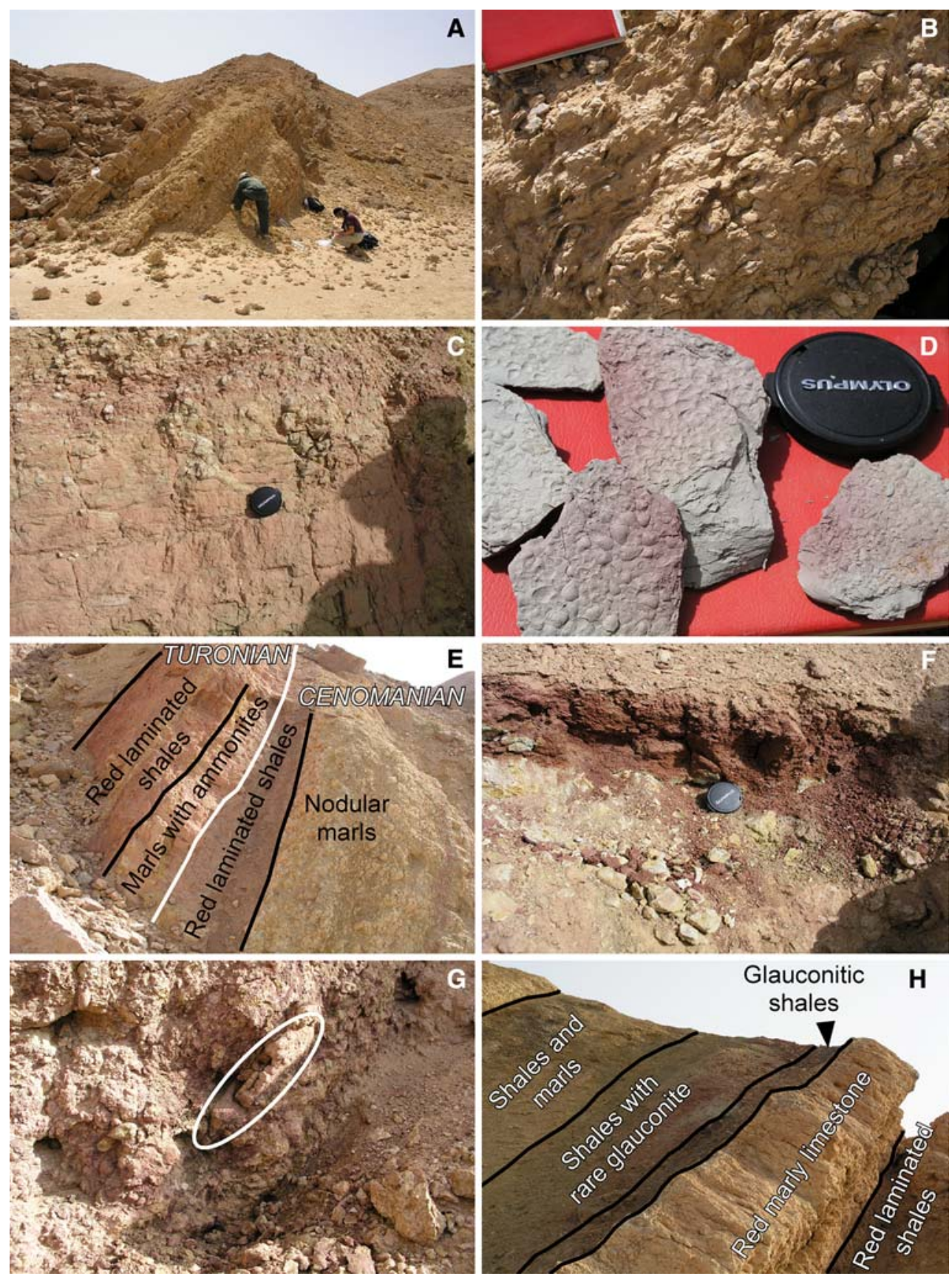

Fig. 3 a Calcareous sandstones $(0-3.2 \mathrm{~m})$ with bioturbation and rare glauconite. b Oysters shells from an oyster biostrome. c Bioturbation and nodules from the nodular marl (18-26 m). d Dwarfed bivalves from the basal nodular marl. e Interval spanning the $\mathrm{C}-\mathrm{T}$ boundary

and red laminated shale. f Red laminated shale. g First Turoanian ammonite V. Proprium. h Wata Formation overlying the red laminated shale

\section{Zone C1-Neolobites vibrayeanus interval zone}

1989; Orabi 1992; Kassab 1994; Kora et al. 1994; Kassab and Ismael 1996; Kassab 1999; El-Sabbagh 2000; Kassab and Obaidalla 2001). Based on these studies and the Whadi El Ghaib section, five ammonite biozones are recognized and summarized below.

This biozone is characterized by the total range of Neolobites vibrayeanus, a Late Cenomanian index species known from the Tethys ocean (El-Sabbagh 2000; Kassab and Obaidalla 2001; El-Hedeny 2002). In the Wadi El Ghaib 


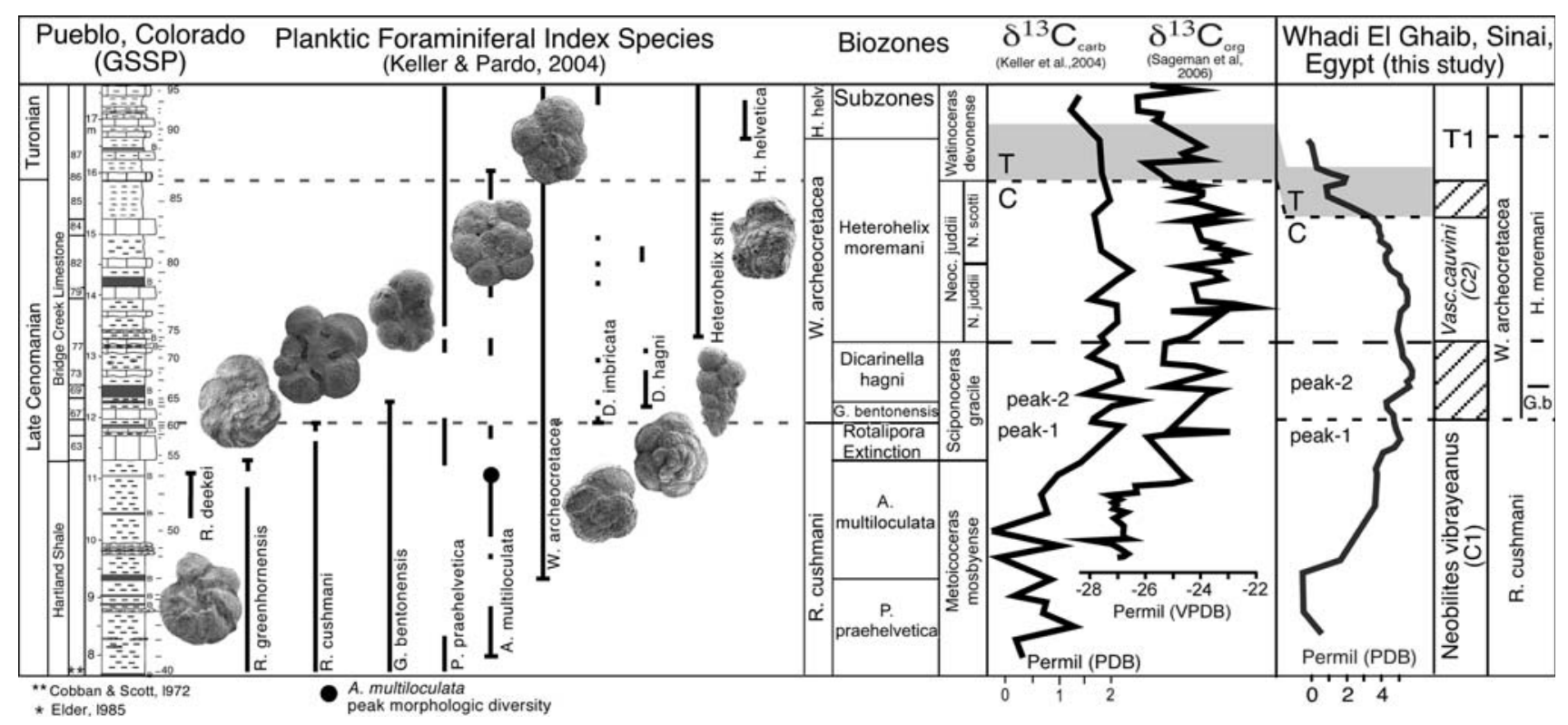

Fig. 4 Comparison of ammonite, planktic foraminifera and carbon and organic carbon isotope biostratigraphies of the Pueblo, Colorado, stratotype and the carbon isotope (smoothed) curve of Whadi El Ghaib, Sinai (modified from Keller and Pardo 2004)

section, this interval also contains the oyster Ilymatogyra aff. africana, though only a single occurrence of $N$. vibrayeanus was observed (sample WG 24, Fig. 5). This suggests that the lower part of the section, including the Raha Formation, are within Zone $\mathrm{C} 1$, which would place zone $\mathrm{C} 1$ below the onset of the $\delta^{13} \mathrm{C}$ shift in the Wadi $\mathrm{El}$ Ghaib. Correlation with the Pueblo, Colorado, stratotype section places the top of this zone in the lower part of the Sciponoceras zone (Fig. 4) (Kassab and Obaidalla 2001).

\section{Zone C2-Vascoceras cauvini interval zone}

The base of this zone is defined by the first appearance (FA) of the nominate species and/or the last occurrence (LO) of $N$. vibrayeanus. The top of zone $\mathrm{C} 2$ is defined by the LO of $V$. cauvini and/or the FAs of $V$. proprium and $V$. obessum. The $V$. cauvini zone $\mathrm{C} 2$ is generally considered as uppermost Cenomanian in age in the Tethys seaway (Kassab 1991, 1999; Meister et al. 1992; Pascal et al. 1993; El-Hedeny 2002). In the Wadi El Ghaib V. cauvini first appears at the base of the Abu Qada Formation, $11 \mathrm{~m}$ above the LO of $N$. vibrayeanus and within the maximum $\delta^{13} \mathrm{C}$ excursion. The $\mathrm{C} 1 / \mathrm{C} 2$ boundary can therefore only be tentatively identified (dashed interval, Figs. 4, 5) and, in this study, is placed at the single last occurrence of $N$. vibrayeanus based on the assumption that the FA of $V$. cauvini is delayed for environmental reasons. This places the $\mathrm{C} 1 / \mathrm{C} 2$ boundary tentatively between 18.5 and $23 \mathrm{~m}$ (Figs. 4, 5). The top of zone $\mathrm{C} 2$ is placed at the last occurrence of the index species $V$. cauvini at $28.5 \mathrm{~m}$. This interval is also marked by the LA of Paramites polymorpheum and disappearances of oysters Exogyra olisiponensis and Ceratostreon flabellum. Correlation with the Pueblo stratotype suggests that zone $\mathrm{C} 2$ encompasses the entire $\delta^{13} \mathrm{C}$ excursion and spans the Neocardioceras ammonite zone (Fig. 4).

\section{Zone T1-Vascoceras proprium/Pseudaspidoceras} flexuosum total range zone

This zone is defined by the total range of the two index species and marks the base of the Turonian (Robaszynski and Gale 1993; Chancellor et al. 1994). At Wadi El Ghaib, the first appearances of the two index species are found immediately above the extinction of $V$. cauvini (Fig. 5). The Cenomanian-Turonian boundary is therefore clearly marked by ammonites and coincides with a lithological change from marl to marly limestone. Based on the carbon isotope correlation with the GSSP Pueblo section and $\mathrm{FO}$ of the $V$. proprium/P. flexuosum, the position of the Cenomanian-Turonian boundary (C2-T1 boundary) occurs between $27.3-28.5 \mathrm{~m}$ at the Whadi El Ghaib section (Figs. 4, 5). Zone T1 spans the middle part of the Abu Qada Formation (28.5-31.5 m). Other taxa present include the ammonites $V$. obessium, Mamites nodosoides and Fagesia catinus, as well as the oyster species Ilymatogyra aff. pseudafricana. Carbon isotope correlation with the Pueblo section suggests that zone T1 correlates with the lower part of the Watinoceras ammonite zone (Fig. 4). 




Fig. 5 Biostratigraphy and species occurrences of ammonites, oysters, planktic and benthic foraminifera and planktic/benthic ratio. Biostratigraphic interpretation is based on fauna and flora, the $\delta^{13} \mathrm{C}$

\section{Zone T2-Choffaticeras segne total range zone}

This lower Turonian zone is defined by the total range of Choffaticeras segne, a species that is synonymous with $C$. luciae, C. pavillieri, C. schweinfurthi, and C. securiforme (Kassab 1985; Kassab and Ismael 1994). The top of the Abu Qada Formation in the Whadi El Ghaib is marked by the first appearance of the index species $C$. segne, whereas $M$. nodosoides and F. catinus disappear in zone T2 (Fig. 5).

\section{Zone T3-Coilopoceras requienianum zone}

This zone is defined by the total range of the index species (Kassab 1991, 1999). In the Whadi El Gahib section, the $\mathrm{LO}$ of $C$. segne and $\mathrm{FO}$ of $C$. requienianum mark the boundary between zones $\mathrm{T} 2$ and $\mathrm{T} 3$.

\section{Planktic foraminiferal biostratigraphy}

Planktic foraminifera range from rare to abundant in four stratigraphic intervals of the Whadi El Ghaib section (Fig. 5). Rotalipora species, including the Late Cenomanian index species $R$. cushmani, are absent in these shallow water sequences. However, age interpretations can be made based on the sporadic assemblages, carbon isotope stratigraphy and correlation with the Pueblo, Colorado, stratotype section and point (Fig. 4).

The first common to abundant assemblage is in an oyster bed (12-16 m, sample 42, Fig. 5) and contains abundant curve of the Whadi El Ghaib and correlation with the Pueblo stratotype section

Hedbergella delrioensis, H. planispira and Whiteinella archeocretacea. This impoverished assemblage indicates a high stress shallow water environment, possibly with frequent fresh water influx (Leckie 1987; Keller and Pardo 2004). The latest Cenomanian index species W. archeocretacea first appears at $13.5 \mathrm{~m}$, near the onset of the $\delta^{13} \mathrm{C}$ shift in the Whadi El Ghaib, as also observed at Pueblo. The base of the $W$. archeocretacea zone is defined by the extinction of all Rotalipora species, which occurs in the trough between $\delta^{13} \mathrm{C}$ peak 1 and 2 (Keller et al. 2001; Kuhnt et al. 1997). At Pueblo, the R. cushmani extinction coincides with the $\delta^{13} \mathrm{C}$ peak 1 because sedimentation in the trough is condensed (Fig. 4) (Keller and Pardo 2004). Based on these correlations, we tentatively place the base of the $W$. archeocretacea zone in the trough between the two $\delta^{13} \mathrm{C}$ peaks (Fig. 4). The interval below the $\delta^{13} \mathrm{C}$ excursion is by definition within the Rotalipora cushmani zone, though rotaliporids are absent in the shallow water Sinai sections.

The second assemblage at $20 \mathrm{~m}$ (sample 56) coincides with the second peak of the $\delta^{13} \mathrm{C}$ excursion and contains abundant low oxygen tolerant Heterohelix moremani and rare Globigerinelloides bentonensis. The last occurrence of G. bentonensis at Pueblo coincides with the second $\delta^{13} \mathrm{C}$ peak. In the Whadi El Ghaib section, G. bentonensis is very rare with a single occurrence at the $\delta^{13} \mathrm{C}$ peak 2 (Fig. 4). Another isolated occurrence, and possibly reworked specimen, was observed at the Cenomanian/Turonian boundary. Another subzone of $W$. archeocretacea is the H. moremani 
abundance acme, which globally marks the dysoxic to anoxic conditions characteristic of the $\delta^{13} \mathrm{C}$ plateau up to the $\mathrm{C} / \mathrm{T}$ boundary and into the early Turonian. Throughout the global ocean, Heterohelix dominated assemblages first appear shortly after the second $\delta^{13} \mathrm{C}$ peak and mark the change to oceanic anoxia (Leckie 1987; Leckie et al. 1998; Keller et al. 2001; Keller and Pardo 2004). The Heterohelix shift defines the base of the H. moremani subzone (Fig. 4) (Keller et al. 2001; Keller and Pardo 2004), which is also present in the Whadi El Ghaib by sporadic though abundant $H$. moremani.

The third assemblage coincides with the ammonite defined $\mathrm{C} / \mathrm{T}$ boundary $(28.5 \mathrm{~m})$ near the end of the $\delta^{13} \mathrm{C}$ excursion and consists of few to common $H$. delrioensis, $H$. planispira, W. baltica, W. archeocretacea and reduced $H$. moremani and Heterohelix sp. (Fig. 5). A similar assemblage is present at $31.5 \mathrm{~m}$ coincident with the ammonite zone T1/T2 boundary. These two assemblages with their reduced abundances of low oxygen tolerant Heterohelix and increased abundances of Whiteinella species mark the end of the anoxic event and return to a more normal oxic water column in the early Turonian. Similar faunal assemblage changes have been observed at Eastbourne, England, Pueblo, Colorado, Tarfaya, Morocco, and Tunisia (Keller et al. 2001, 2004, 2008; Keller and Pardo 2004; Nederbragt and Fiorentino 1999).

\section{Benthic foraminiferal biostratigraphy}

Benthic foraminiferal assemblages are more diverse and abundant than planktic foraminifera in the shallow water Wadi El Ghaib section. The most abundant assemblage components are low oxygen tolerant species, particularly the infaunal species Coryphostoma plaitum and Fursenkoina nederi, the epifaunal Gavelinella sandidgei, and Praebulimina aspra and P. nannina (Fig. 5). The remainder of the assemblages also consists of low oxygen tolerant species, though they tend to be rare and sporadic, including Pleurostomella sp., Ammobaculites plummerae, Pyramidina prolixa and Gaudryina sp. These low oxygen tolerant assemblages dominate in ammonite zone $\mathrm{C} 1$ spanning the $\delta^{13} \mathrm{C}$ excursion and indicate dysaerobic bottom conditions and high nutrient influx. This is particularly evident during deposition of the thick oyster bed $(12-16 \mathrm{~m})$, which marks the onset of the $\delta^{13} \mathrm{C}$ excursion. In the lower part of the section (zone C1), benthic foraminifera are rare, including Dentolina $s p$. and $A$. foliacea.

In the upper part of the section, just below and above the $\mathrm{C}-\mathrm{T}$ boundary, the red laminated sediments are devoid of planktic and benthic foraminifera, gastropods and echinoids (shaded interval, Fig. 5). The laminations of the red shale indicate that these were originally dark organic-rich sediments, which were later diagenetically altered to a red ochre color because the in-situ pyrite has been oxidized and destroyed.

\section{Mineralogy}

Bulk rock

Calcite, quartz and phyllosilicates are the dominant minerals (Fig. 6). The three-point average curve shows the overall trends of each mineral, except for plagioclases, K-feldspaths and the calcite/detritus ratio. Phyllosilicates and unquantifieds show similar trends, suggesting that most of the unquantifieds may be phyllosilicates. The basal part of the section (0-12 $\mathrm{m}$ ) below the thick oyster-rich limestone is dominated by quartz $(20-60 \%)$, phyllosilicates (20\%) and plagioclases (5\%). Calcite is almost absent, except in the oyster-rich limestone beds, where it is the dominant mineral (70-90\%) from the thick oyster beds to the marly limestone of the lower Abu Qada Formation (12$27 \mathrm{~m}$ ). In the same interval, quartz and plagioclase disappear and phyllosilicates decrease $(10 \%)$. The uppermost part of the section $(27-38 \mathrm{~m})$ consists of alternating intervals dominated by calcite and quartz/phyllosilicates. The detrital index $[\mathrm{C} / \mathrm{D}=$ Calcite/(Quartz + Phyllosilicates + K-Feldspars + Na-Plagioclases)] shows highest values between 12 and $27 \mathrm{~m}(10-100)$, between 32 and $33 \mathrm{~m} \mathrm{(100)}$ and at $37 \mathrm{~m} \mathrm{(70),} \mathrm{whereas} \mathrm{low} \mathrm{values} \mathrm{indicate}$ high detritus in the rest of the section.

\section{Clay mineralogy}

Clay assemblages (fraction $<2 \mu \mathrm{m}$ ) of the Whadi El Ghaib section are composed of kaolinite, chlorite, smectite, illite, palygorskite and I-S mixed layer (Fig. 7). A threepoint average curve shows the overall trend of each type of clay, except for I-S mixed layer and palygorskite. Kaolinite $(60-80 \%)$ is the main clay of the basal $20 \mathrm{~m}$, whereas smectite contents remain low (10-40\%). An abrupt decrease in kaolinite $(<5 \%)$ and rapid increase in smectite (90\%) occurs at $21 \mathrm{~m}$. Smectite $(50-90 \%)$ remains the dominant clay mineral from 21 to $25 \mathrm{~m}$, then gradually decreases reaching minimum values at $33 \mathrm{~m}$ in the early Turonian. Kaolinite and chlorite show three peaks in the middle of the Abu Qada Formation (26.5-31.5 m). Above this interval, the upper part of the limestone/shale interval of the Abu Qada Formation (31.5-35 m) is marked by alternating dominance of illite (80-90\%) and palygorskite $(60-80 \%)$, and the absence of kaolinite and smectite. The uppermost part of the section is characterized by the return to high smectite and increased kaolinite and chlorite contents $(40-80 \%)$. 


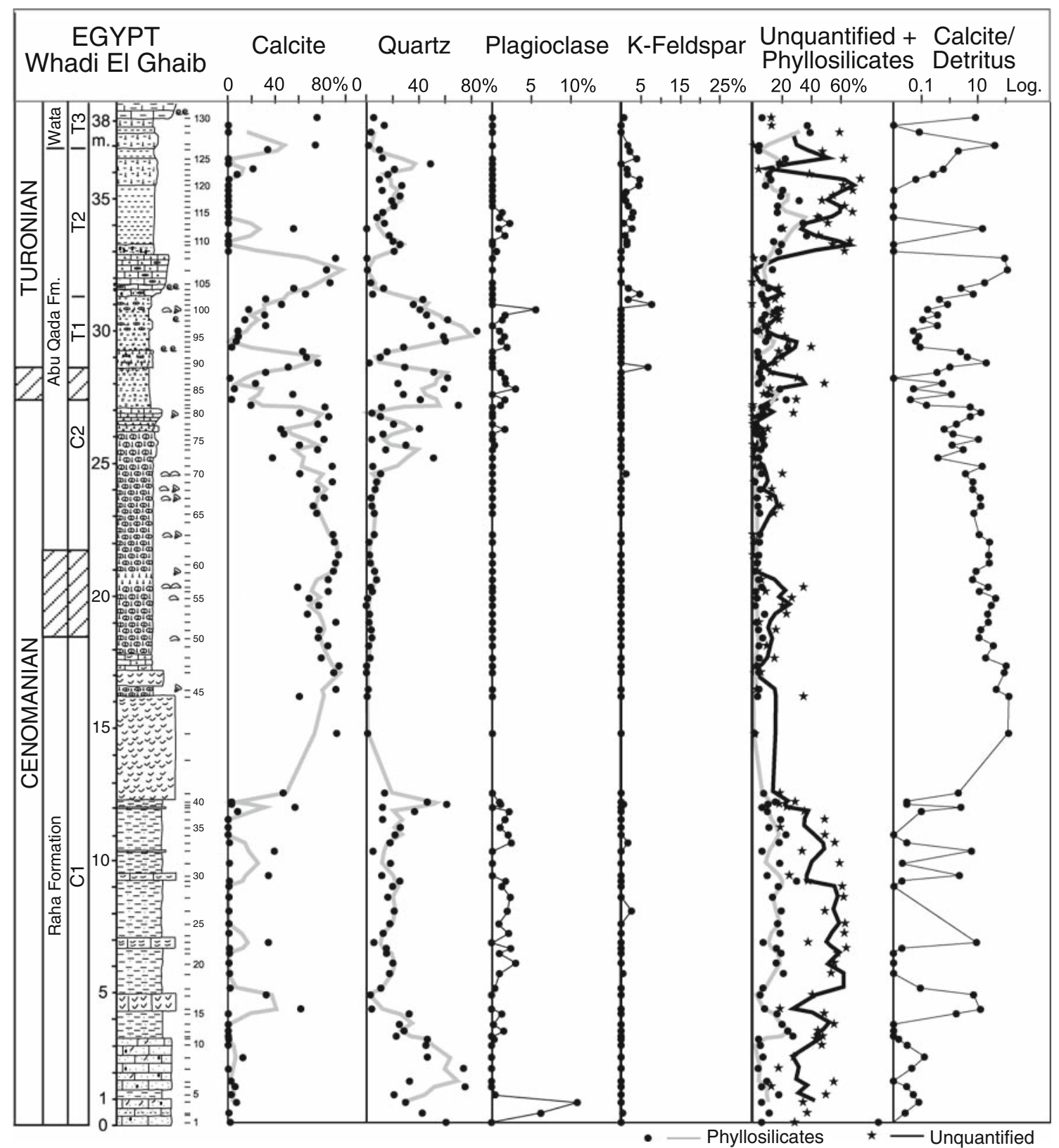

Fig. 6 Bulk rock analysis of the Whadi El Ghaib section. Grey lines mark the three-points moving average for calcite, quartz, phyllosilicates and unquantified. Calcite is dominant in oyster beds. High detrital influx marks more humid climate and increased weathering and runoff

\section{Oxygen and carbon isotopes}

The reliability of $\delta^{18} \mathrm{O}$ and $\delta^{13} \mathrm{C}$ isotopes in bulk rock sediments is largely dependent upon the degree of diagenesis in the sediments, which primarily affects oxygen isotope values (e.g., Schrag et al. 1995). In particular, the effects of pore waters and/or recrystallization leads to very negative $\delta^{18} \mathrm{O}$ ratios and consequently to significant lowering of the oxygen isotope ratios in sediments. In contrast, $\delta^{13} \mathrm{C}$ isotopes are little affected by diagenesis, except in sediments influenced by organogenic carbon (Marshall
1992). This may have influenced $\delta^{13} \mathrm{C}$ values of the originally organic-rich laminated shales (samples WG80WG89 and WG92-WG100). However, a cross-plot of $\delta^{13} \mathrm{C}$ and $\delta^{18} \mathrm{O}$ isotope data as well as $\delta^{13} \mathrm{C}$ and percent carbonate shows no significant correlation (respectively, $R^{2}=0.259$ and $R^{2}=0.556$ ) for the Whadi El Ghaib section (Fig. 8). $\delta^{18} \mathrm{O}$ values range from -9 to $-2 \%$ and $\delta^{13} \mathrm{C}$ values range between -1 and $6 \%$. The relatively low $\delta^{18} \mathrm{O}$ isotope ratios imply a significant diagenetic overprint due to the high capacity of oxygen exchange with interstitial fluids. These data are therefore unreliable as proxies for 


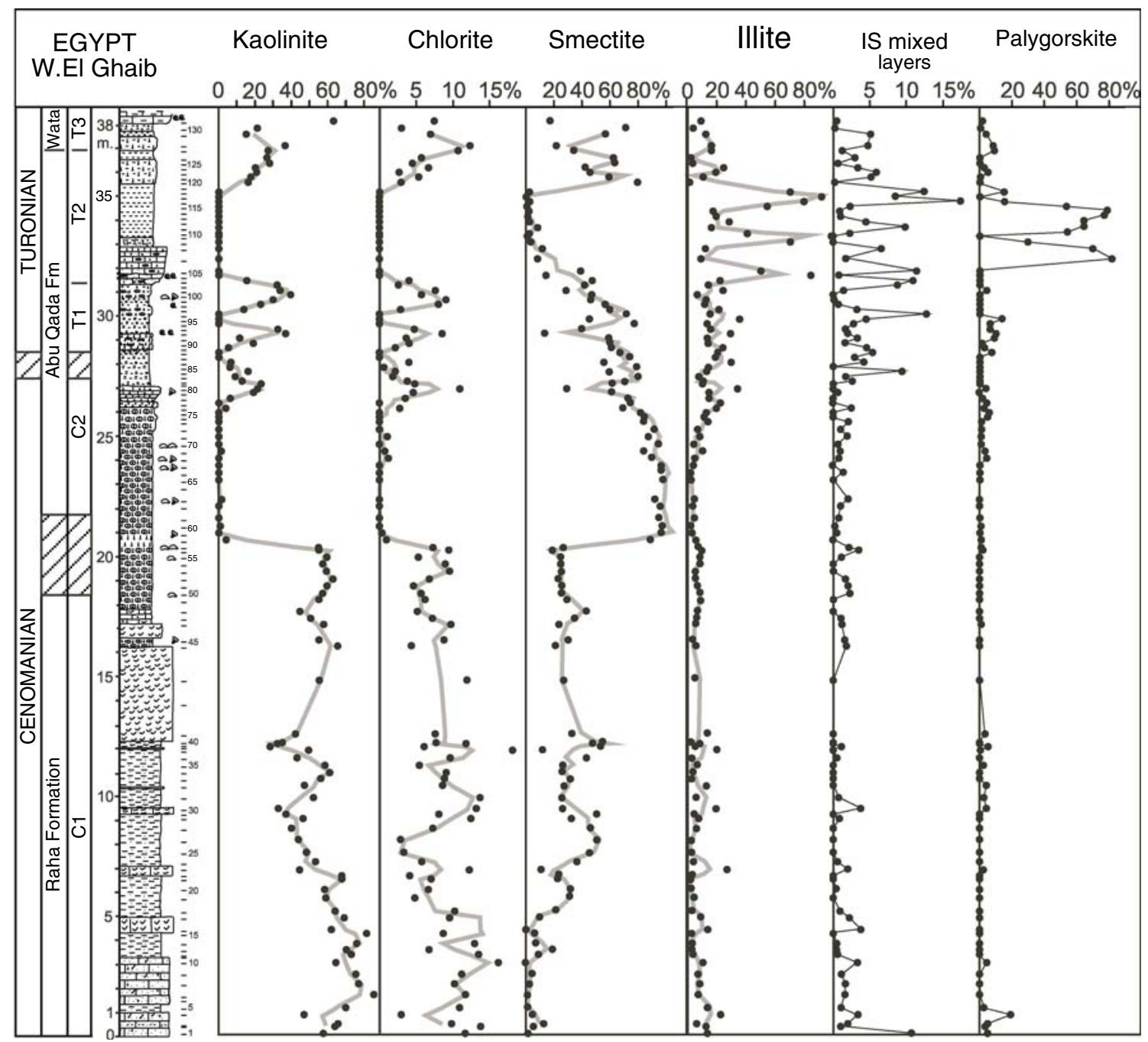

Fig. 7 Clay mineralogical analysis of the Whadi El Ghaib section. Dominant kaolinite marks humid climatic conditions in the lower $21 \mathrm{~m}$ of the section. Dominant smectite, interrupted by illite and palygorskite (31 and $35 \mathrm{~m}$ ) suggests dry and seasonal climate conditions. Grey lines mark the three-points moving average
Fig. 8 Cross-plot of $\delta^{13} \mathrm{C}$ and $\delta^{18} \mathrm{O}$ values, and of $\delta^{13} \mathrm{C}$ and percent carbonate for the Whadi El Ghaib section. Note that there is no significant correlation between $\delta^{13} \mathrm{C}$ and $\delta^{18} \mathrm{O}$, or between $\delta^{13} \mathrm{C}$ and percent carbonate indicating that late diagenetic overprinting affected mainly $\delta^{18} \mathrm{O}$, as also suggested by high negative values

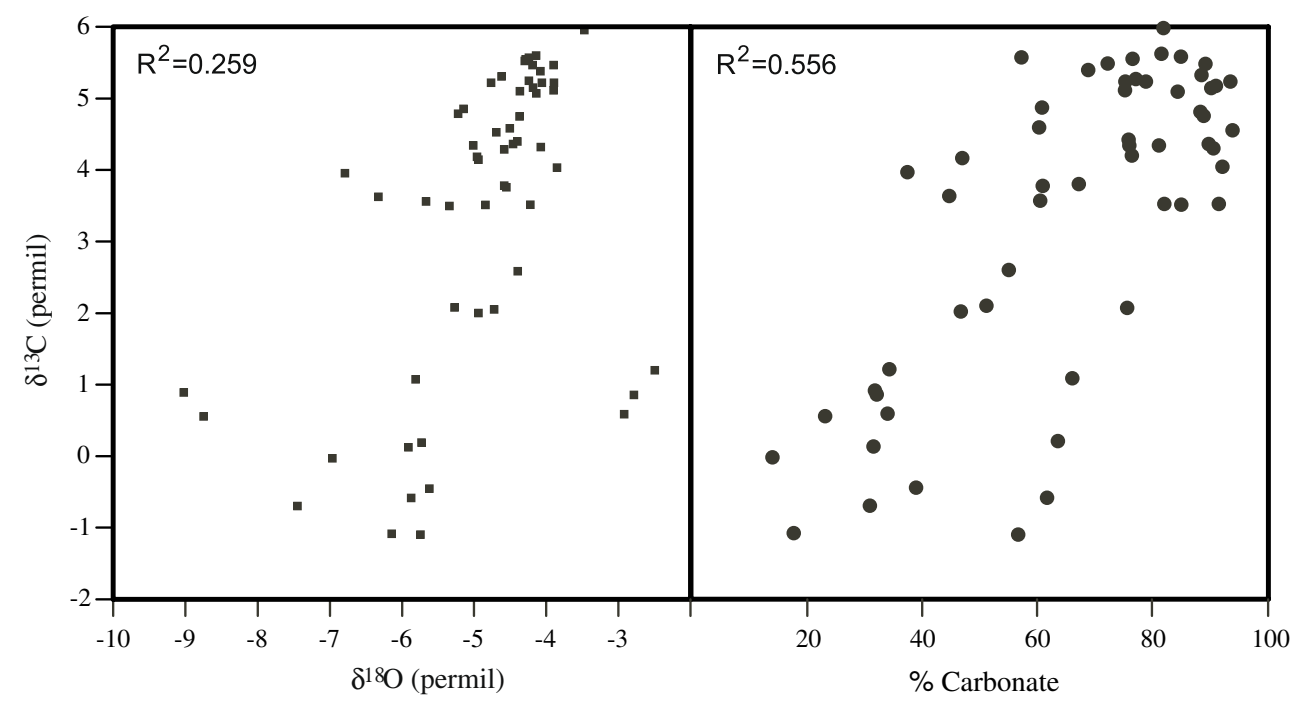


temperature trends and are not discussed further. Carbon isotopes are less affected by this type of diagenesis due to the scarcity of carbon in pore waters.

The carbon isotope curve shows relatively low values $(-1 \%)$ in the lower part of the section (4-12 m, Fig. 9).
In the $5 \mathrm{~m}$ thick oyster-rich limestone, $\delta^{13} \mathrm{C}$ values increase and reach $4 \%$, followed by a further increase to $5 \%$ above the oyster-rich limestone in the nodular marl (17-19 $\mathrm{m})$. This marks the global $\delta^{13} \mathrm{C}$ excursion and first peak. Above it, $\delta^{13} \mathrm{C}$ values drop to $4 \%$ o (18.5-19.5 m)

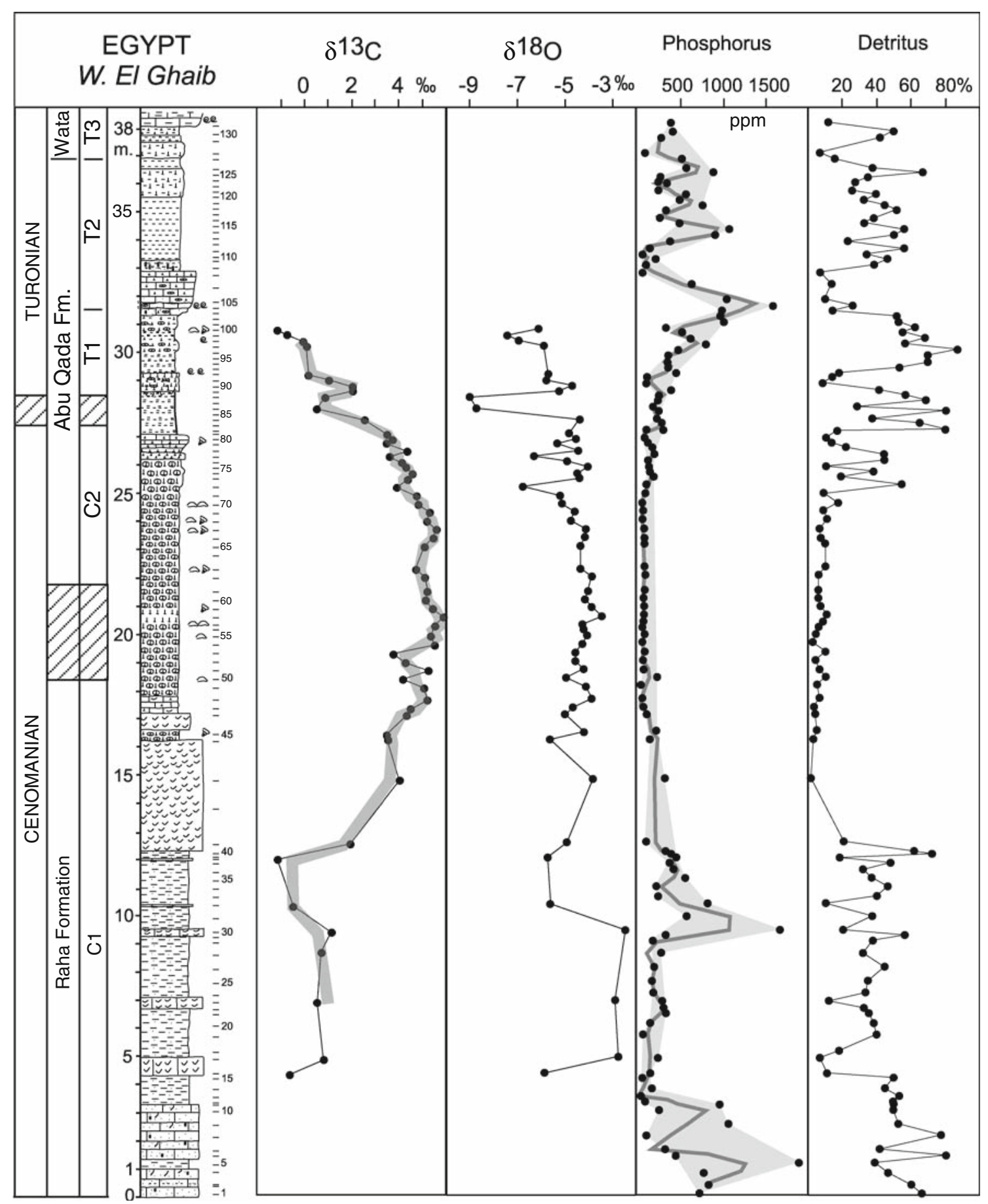

Fig. $9 \delta^{13} \mathrm{C}$ and $\delta^{18} \mathrm{O}$, phosphorus concentrations and detritus (quartz $+\mathrm{K}$-feldspath + plagioclases + phyllosilicates) of the Whadi El Ghaib section. The $\delta^{13} \mathrm{C}$ curve shows the characteristic positive excursion of the late Cenomanian OAE2. Highly negative $\delta^{18} \mathrm{O}$ values are due to diagenetic alteration. Peak phosphorus concentrations $(10$ and $32 \mathrm{~m})$ straddle the $\delta^{13} \mathrm{C}$ excursion and correlate with increased detritus, suggesting that phosphorus is primarily of detrital origin 
then rapidly increase to $6 \%$ at $20 \mathrm{~m}$, which marks the second peak of the global $\delta^{13} \mathrm{C}$ excursion. $\delta^{13} \mathrm{C}$ values remain steady between $5-6 \%$ up to $24 \mathrm{~m}$ then gradually decrease to $-1 \%$ by the lower part of the Abu Qada Formation.

\section{Phosphorus accumulation}

Total phosphorus contents range from 100 to $2,000 \mathrm{ppm}$ (Fig. 9). High values (200-1,000 ppm with a peak at 2,000 ppm) are reached in the basal $3 \mathrm{~m}$ of the Raha Formation. Phosphorus contents stabilize at $200-400 \mathrm{ppm}$ (4-9 m), increase to a maximum of 1,500 ppm between 9$10 \mathrm{~m}$ and gradually decrease to low values $(10-12.5 \mathrm{~m})$. The base of the $5 \mathrm{~m}$ thick oyster-rich limestone bed up to the $\mathrm{C}-\mathrm{T}$ boundary $(12.5-28.5 \mathrm{~m})$ is low in phosphorus $(\sim 300 \mathrm{ppm})$. A gradual increase occurs in the T1 ammonite zone and reaches a maximum $(1,500 \mathrm{ppm})$ at the boundary between the $\mathrm{T} 1$ and $\mathrm{T} 2$ ammonite biozones. The upper part of the section $(33-38 \mathrm{~m})$ shows three small peaks between 600 and 1,000 ppm.

\section{Interpretations}

Micro- and macrofossils as environmental proxies

Planktic and benthic foraminiferal assemblages in the Whadi El Ghaib section consist of low diversity and low oxygen tolerant species that reflect nutrient-rich, dysoxic to anoxic conditions in a coastal environment. This is indicated by sporadic occurrence of planktic foraminiferal assemblages with small simple morphologies ( $r$-strategists, Hedbergella, Heterohelix, Globigerinelloides and Whiteinella), which mainly lived in the upper water column (Hart 1980, 1999; Petters 1980; Jarvis et al. 1988; Leckie et al. 1998; Price and Hart 2002; Keller and Pardo 2004). The low oxygen tolerant heterohelicids and low salinity tolerant hedbergellids are the first to colonize new seaways and among the last to survive in shallow inner neritic environments (Eicher and Worstell 1970; Douglas and Savin 1978; Leckie 1987; Leckie et al. 1998; Keller and Pardo 2004). These shallow environments are often characterized by high nutrients due to terrigenous runoff and low salinity due to fresh water influx.

In the Whadi El Ghaib, these conditions are indicated not only by heterohelicids and hedbergellids, but also by the presence of agglutinated benthic species (i.e. Ammobaculites and Spiroplectamina) associated with hyaline species, but generally without porcellaneous forms (Murray 1973). Seafloor dysoxic/anoxic conditions are indicated by infaunal benthic assemblages, except for one species $(G$. sandidgei). These infaunal deposit feeders are the first to profit from high food availability (Corliss and Chen 1988; Koutsoukos et al. 1990; Leary and Peryt 1991; Paul et al. 1994; Perty and Lamolda 1996). The paleowaterdepth in this inner neritic environment ranged from $0-50 \mathrm{~m}$, as also suggested by the oyster-rich limestones. By the latest Cenomanian to early Turonian the sea level transgression resulted in a deeper middle neritic environment, as also suggested by the increased planktic/benthic ratio and reduced benthic diversity. This deepening environment was accompanied by anoxia, as indicated by deposition of laminated and originally organic-rich shale devoid of both benthic and planktic foraminifera (Fig. 5).

The most common macrofossils, other than oysters, in the Whadi El Ghaib section are gastropods, echinoids and ammonites. Gastropods are found in the intertidal flats and in shallow subtidal environments (Nield and Tucker 1985). Turritella, Cerithium, Tylostoma and Nerinea inhabited warm water normal marine inner to middle neritic conditions (Nield and Tucker 1985). Echinoderms, which are present in the upper part of the section, inhabited littoral to sublittoral environments with normal salinity, and the neritic zone commonly associated with reefs (Nield and Tucker 1985). Ammonites lived in both shallow and open marine environments, but were most common in normal marine to middle neritic environments at water depths up to $300 \mathrm{~m}$ (Kassab 1985; Kassab and Ismael 1994). In the Whadi El Ghaib section ammonites are most commonly present in the deeper water environment of the early Turonian.

A key feature of the Whadi El Ghaib section is the presence of oyster-rich limestone beds during the late Cenomanian, as also observed in Morocco (Andreu 1989), in Sinai (Bauer et al. 2003) and Jordan (Schulze et al. 2003, 2004, 2005). During the Cretaceous, oysters typically inhabited shallow-water environments of the Tethys near North Africa where they first appeared during the late Aptian (Algeria and Morocco) and formed specific facies since the Cenomanian (Dhondt et al. 1999). In the Sinai, oysters are abundant from the Cenomanian through the middle Turonian and from the late Turonian through middle Coniacian (Bauer et al. 2003; Malchus 1990), but are scarce at times of high sea-levels (Dhondt et al. 1999).

Neogene to recent oyster beds yield environmental information pertinent to coastal areas of the Sinai and elsewhere during the late Cenomanian. In Australia, Pliocene oyster buildups identify three types of oyster deposits (e.g., bioherms, biostromes and subaqueous dunes) in shallow subtidal environments (Pufahl and James 2006). Applying their classification of oyster deposits, the five upper Cenomanian oyster-rich limestone layers of the Whadi El Ghaib section can be identified as tabular oyster biostromes, which are indicative of shallow subtidal 
environments where oyster shells accumulated in horizontal positions without stratification or grading. These beds laterally range from a few hundreds of meters up to $4 \mathrm{~km}$ (Abed and Sadaqh 1998).

Oyster buildups form in high-energy, shallow and faunally restricted environments with low salinity, mesotrophic nutrient level, a turbid water column and high spatial homogeneity of oyster communities (Pufahl and James 2006). They are extremely efficient filters, tolerate a wide range of environmental conditions (e.g., $r$-strategists) and respond quickly to environmental perturbations. In these aspects, oysters are opportunistic species, similar to the planktic foraminifera Guembelitria, a disaster opportunist that thrived in nutrient-rich surface waters, and low oxygen tolerant Heterohelix and salinity tolerant Hedbergella species (Keller and Pardo 2004).
In the Whadi El Ghaib section, the presence of thick oyster biostromes in the middle of the section is controlled by climate and sea level changes. Clay mineralogy suggests that humid climate conditions prevailed up to the second $\delta^{13} \mathrm{C}$ peak, resulting in fresh water influx and hence low salinity, but high nutrient influx (Fig. 10). Sea level was generally rising, though fluctuating during the time of the $\delta^{13} \mathrm{C}$ excursion (Haq and Hardenbol 1987; Gale et al. 2002; Jarvis et al. 2006). Oysters thrived under such conditions forming biostromes, whose thickness was mainly driven by a rising sea level. Their termination reflects drowning of the reefs as the sea level rise outpaces oyster growth.

Sageman et al (2006) calculated a duration of 150,000 years from the onset to the first peak of the $\delta^{13} \mathrm{C}$ excursion at Pueblo, Colorado. Based on this estimate, and assuming constant sedimentation rates and continuous

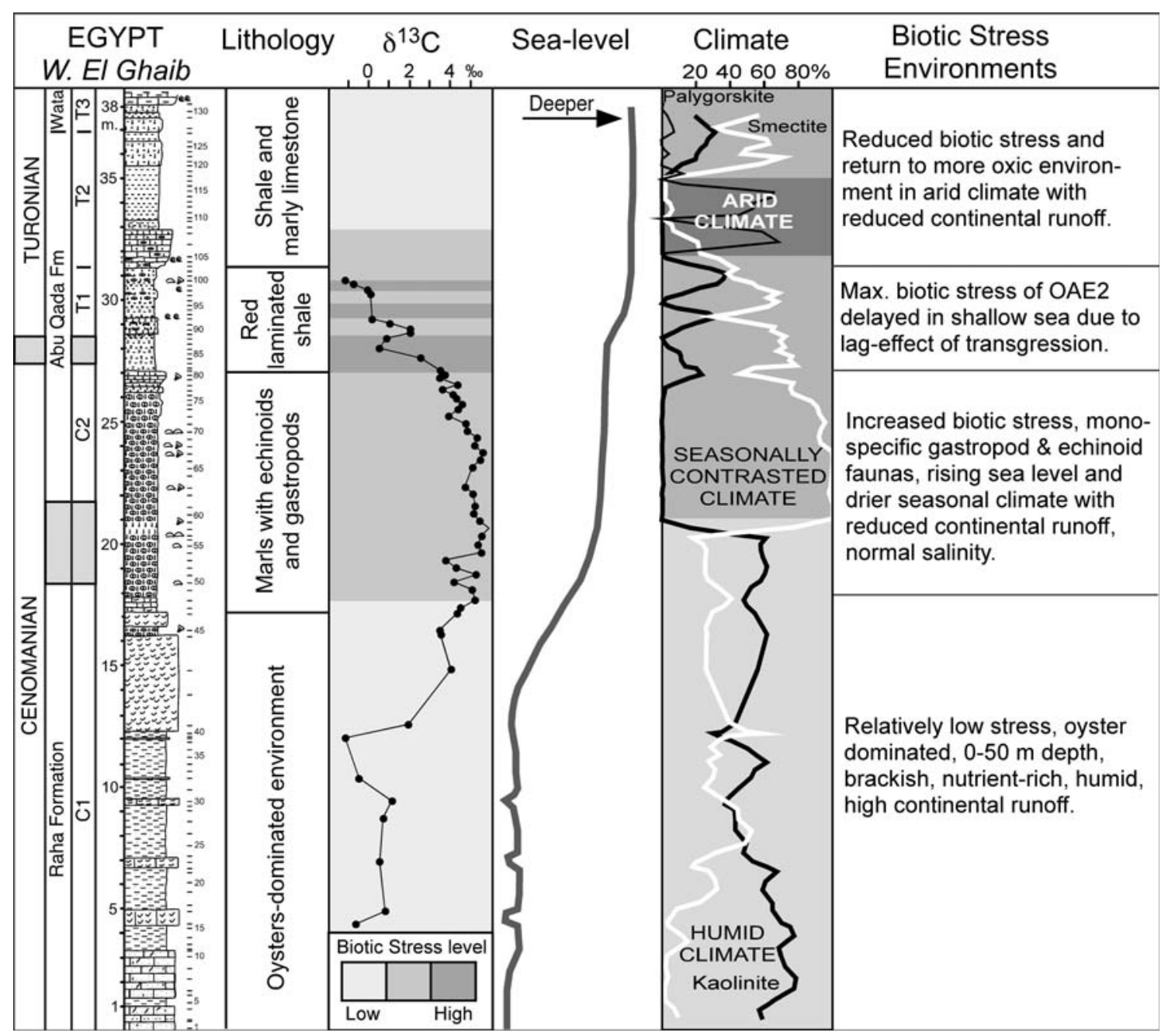

Fig. 10 Summary of environmental proxies, including $\delta^{13} \mathrm{C}$, sea level and climate changes inferred from sedimentology, mineralogy and faunal assemblages, across the $\mathrm{C}-\mathrm{T}$ transition at the Whadi El Ghaib. The $\delta^{13} \mathrm{C}$ excursion that marks OAE2 in open marine environments also reached into shallow coastal settings, but that the dysoxic/anoxic conditions were delayed until the maximum transgression transported this watermass into shallow coastal areas 
deposition, the last oyster bed in the Wadi El Ghaib may have been deposited in about $100 \mathrm{ky}$ with the $\delta^{13} \mathrm{C}$ peak reached during the last $50 \mathrm{ky}$ of limestone and marl deposition.

\section{Mineralogy as environmental index}

Bulk rock and clay mineralogy, including the detrital index (C/D ratio) and clay contents, provide an environmental and climate index. In the Whadi El Ghaib, the low detrital index indicates high continental runoff, whereas high values show low continental runoff. However, this interpretation is not valid in oyster-rich limestone beds, because oyster growth is dependent on high nutrient influx, which largely comes from continental runoff in shallow coastal environments.

Clay minerals form in terrestrial soils and are eroded and transported to the oceans. The major clay minerals are kaolinite and smectite. Kaolinite forms under humid conditions in equatorial soils, whereas smectite forms in tropical soils in dry, seasonal climate conditions, or from alteration of basalts (Chamley 1989). Distribution of clay minerals in sediments can be influenced by authigenesis (Chamley 1989; Kübler and Jaboyedoff 2000) and differential settling of kaolinite versus smectite in the water column (Godet et al in press). Diagenetic transformation due to burial (e.g., authigenesis) generally occurs at sediment depths $>2 \mathrm{~km}$ (Chamley 1989). Thus, diagenetic changes are not a significant influence in clay assemblages of the Whadi El Ghaib section, which was buried under about $1 \mathrm{~km}$ of sediments.

Differential settling cannot be evaluated based on a single sequence and requires correlation with deeper water sections, which are not known from this area. The paleoenvironmental reconstructions for the late Cenomanianearly Turonian of the Sinai suggest that there was no significant carbonate platform at that time (Luning et al 1998). Within these constraints, the basal $17 \mathrm{~m}$ of the Whadi El Ghaib section were deposited under humid climate conditions and high continental runoff, as suggested by high kaolinite, low C/D ratios and oyster-rich limestone (Figs. 6, 7). Low detrital input, high calcite values and a switch to seasonally contrasted climate characterize the nodular marls interval $(17-27 \mathrm{~m})$. The increasingly deepening environment of the upper part of the section (27$38.5 \mathrm{~m}$ ) shows fluctuating, but increasing detrital input in both laminated and non-laminated shales, with inversely fluctuating calcite. A seasonally contrasted climate prevailed, except in the shale interval $(33-35.5 \mathrm{~m})$ where more arid conditions are indicated by local high palygorskite, high illite and IS mixed layers, which are products of mechanical erosion.

\section{Geochemistry}

\section{Carbon isotope}

The late Cenomanian OAE2 is characterized by a worldwide positive excursion in $\delta^{13} \mathrm{C}$ (Arthur et al. 1988; Jenkyns et al. 1994; Tsikos et al. 2004). The typical shape of the late Cenomanian $\delta^{13} \mathrm{C}$ excursion, as for the GSSP section at Pueblo (Keller et al. 2004; Sageman et al. 2006), shows a rapid increase in $\delta^{13} \mathrm{C}$ to reach the first peak, a short decrease of about $0.6 \%$ forming a trough, followed by a second peak and prolonged plateau (Fig. 4). These features are also observed in the Whadi El Ghaib carbon isotope record and agree with the carbon isotope curve of Pueblo, Colorado, as well as deeper marine sequences (Kolonic et al. 2005; Keller et al. 2008). However, the exact position of the first and second peaks is difficult to determine. The position of the first peak occurs between samples WG48 and WG51. The second peak occurs after the trough and thus is easier to observe.

The amplitude of the $\delta^{13} \mathrm{C}$ values at Whadi El Ghaib is generally $2-3 \%$ higher than at Pueblo (Fig. 4), but is fully comparable to the studied sections in England (Jarvis et al. 2006) where values of $5 \%$ are generally reached for the first and second peaks, as well as for the plateau. The Pueblo section was deposited in the Western Interior Sea and was perhaps influenced by more local conditions, as shown by salinity variations due to changes in precipitations, freshwater influx, marine incursions and long-term sea-level fluctuations (Keller et al. 2004), which could explain the lower $\delta^{13} \mathrm{C}$ values. At Pueblo, the onset of the decrease in carbon isotope values occurs at the $\mathrm{C}-\mathrm{T}$ boundary and permits correlation with Whadi El Ghaib (Fig. 4). After the $\mathrm{C}-\mathrm{T}$ boundary, $\delta^{13} \mathrm{C}$ values decrease rapidly in both areas, followed by a short $1-2 \%$ peak in the early Turonian of Wadi El Ghaib (grey area in Fig. 4).

The similarity in the $\delta^{13} \mathrm{C}$ excursions between the shallow Whadi El Ghaib section and continental shelf of Pueblo suggests that the Whadi El Ghaib section preserves a relatively complete sequence without evidence of a significant lower Turonian hiatus, as earlier postulated for other sequences of the Sinai by Bauer et al. (2001, 2003). Moreover, carbon isotope stratigraphy strengthens the ammonite biozone intercorrelations developed by Kassab and Obaidalla (2001). Based on the $\delta^{13} \mathrm{C}$ data we can infer that the Sinai was directly linked with the open ocean via a large ramp (Luning et al. 1998). The Whadi El Ghaib section thus demonstrates that the OAE2 was not restricted to deeper open marine environments, but reached into shallow marginal marine areas with similarly dire biotic consequences (Davey and Jenkyns 1999; Gertsch et al. 2008 , in preparation). 


\section{Phosphorus}

Total phosphorus quantification analysis was performed to test the hypothesis that upper Cenomanian redox-influenced phosphate accumulation preferentially occurs under oxic conditions prior to and after the $\delta^{13} \mathrm{C}$ excursion (Mort et al. 2007). Low phosphorus accumulation rates would therefore be expected during the dysoxic/anoxic conditions of the $\delta^{13} \mathrm{C}$ excursion, as demonstrated by Mort et al. (2007) in open marine to shelf environments. The Whadi El Ghaib section generally supports this principle, as maximum phosphorus concentration occurred prior to and after the $\delta^{13} \mathrm{C}$ excursion (Fig. 9). Nevertheless, the pattern of phosphorus accumulation is puzzling, showing distinct sharp peaks, rather than sustained high values as expected under oxic conditions. This suggests that, in addition to oxic conditions, other factors may influence preferential phosphorus accumulation, confirming that it is rather unlikely that phosphorus recycling occurs in such shallow environments. A dysoxic water column, delayed high stress conditions and highly variable sedimentation rates, inferred from biostratigraphy and sedimentology also argue against significant redox phosphorus recycling.

A possible explanation for the trends seen in the shallow water environments of the Whadi El Ghaib section is that most of the phosphorus has a detrital origin. Phosphorus trends fit nicely with detrital minerals (quartz, phyllosilicates, K-feldspath and plagioclases; Fig. 9), which are transported by continental runoff. This trend is clear in the basal $27 \mathrm{~m}$, although a possible additional influence of dysoxic conditions during the $\delta^{13} \mathrm{C}$ plateau may be postulated (Mort et al. 2007). Within the laminated shales with rare or no fauna $(27-30 \mathrm{~m})$ reflecting increasing dysoxic conditions, phosphorus concentrations remain low, but increase significantly upward due to higher detrital influx. In the overlying red marly limestone, high phosphorus contents do not correlate with high detrital input, and may be explained by greater oxygen availability in pore waters allowing the precipitation of inorganic phases. In the upper part of the section, scattered phosphorus peaks likely indicates a detrital origin for the phosphorus.

\section{Depositional and environmental scenario}

The Whadi El Ghaib provides an ideal sequence for the study of the environmental evolution, including climate, sea-level changes and anoxia during OAE2 in shallow shelf environments (Fig. 10). During deposition of the lower $17.5 \mathrm{~m}$ of the section, a low sea-level prevailed $(<20 \mathrm{~m})$ with low salinity in a humid climate. High continental runoff and high nutrients influx $(\mathrm{P})$ favored the formation of oysters-dominated reefs in relatively low stress environments. The disappearance of large oyster communities appears to be linked to the rising sea level ( $\sim 50 \mathrm{~m}$, Haq and Hardenbol 1987), a change to more seasonally dry conditions and hence less continental runoff. The lag time between the oyster shut off and the climate change can be explained by the rising sea level, which reworked kaolinite. For this reason, the onset of the climate change is difficult to ascertain during the sea level transgression. The sea level rise was accompanied by $\delta^{13} \mathrm{C}$ excursion.

The $\delta^{13} \mathrm{C}$ plateau coincides with deposition of nodular marls in deeper water with normal salinity, as indicated by the presence of abundant echinoids. The nearly monospecific gastropods assemblages, together with benthic foraminiferal assemblages, reflect increasingly dysoxic waters and higher stress conditions. A seasonally contrasted drier climate with less continental runoff prevailed during this time.

The red laminated shale $(27-30.3 \mathrm{~m})$ is characterized by the absence of benthic fauna, bioturbation and foraminifera, but contains rare ammonites. This interval was deposited under anoxic and/or euxinic waters and thus, reveals maximum biotic stress conditions, which interestingly occurred at the end of the $\delta^{13} \mathrm{C}$ excursion, rather than immediately following it as in open marine environments (e.g., Eastbourne, Tarfaya, Pueblo). This delay in anoxia may be related to the coastal environment of the Wadi El Ghaib and the lag-effect of the sea level transgression. For example, the dysoxic/anoxic conditions that developed during the $\delta^{13} \mathrm{C}$ excursion in deeper and open marine may have subsequently been carried into coastal environments with the sea-level transgression. This would suggest that although the $\delta^{13} \mathrm{C}$ excursion is coeval, the biotic stress conditions (dysoxia/anoxia) are delayed in very shallow continental settings. A return to more oxic conditions, lower biotic stress and arid climate (palygorskite) with reduced continental runoff is indicated in the shale and red marly limestone at the top of the section (Fig. 10).

\section{Conclusions}

1. The Whadi El Ghaib section demonstrates that the late Cenomanian $\delta^{13} \mathrm{C}$ excursion associated with OAE2 and known from open marine environments was also recorded in shallow marginal seas and therefore was not only global, but encompassed shallow to deep, open marine to restricted environments.

2. The Whadi El Ghaib section is comparable to the GSSP Pueblo, Colorado, section as indicated by similar $\delta^{13} \mathrm{C}$ profiles, which together with ammonite and planktic foraminiferal biostratigraphies provide good age control. No hiatus is apparent at the $\mathrm{C}-\mathrm{T}$ boundary.

3. The $\delta^{13} \mathrm{C}$ excursion is coeval in open marine and the restricted shallow setting of the Whadi El Ghaib, but 
the oceanic anoxia/dysoxia conditions and associated biotic stress are delayed, possibly because anoxic waters may have been carried towards shorelines with the sea level transgression after OAE2 developed fully in the open ocean.

4. Foraminiferal assemblages are characterized by low species diversity, high stress planktic and benthic species, tolerance of low oxygen and low salinity conditions. These assemblages are characteristic of dysoxic coastal environments, including OAE2.

Acknowledgments We thank Haydon Mort for advise on phosphorus methods, comments and suggestions. We thank Thomas Steuber and one anonymous reviewer for their helpful comments. This material is based upon work supported by the National Science Foundation under Grant no. 0217921.

\section{References}

Abdel-Gawat GI (1999) Biostratigraphy and facies of the Turonian in west central Sinai, Egypt. Ann Geol Surv Egypt XXII:99-114

Abed AM, Sadaqah R (1998) Role of upper Cretaceous oyster bioherms in the deposition and accumulation of high-grade phosphorites in central Jordan. J Sedim Res 68:1009-1020

Adatte T, Stinnesbeck W, Keller G (1996) Lithostratigraphic and mineralogic correlations of near $\mathrm{K} / \mathrm{T}$ boundary sediments northeastern Mexico: Implications for origin and nature of deposition. The Cretaceous-tertiary event and other catastrophes in Earth history, Boulder, Colorado. Geol Soc Am Spec Pap 307:211-226

Andreu B (1989) Le Crétacé moyen de la transversale Agadir-Nador (Maroc): precisions stratigraphiques et sédimentologiques. Cretac Res 10:49-80. doi:10.1016/0195-6671(89)90029-3

Arthur MA, Dean WE, Pratt LM (1988) Geochemical and climatic effects of increased marine organic-carbon burial at the cenomanian turonian boundary. Nature 335:714-717. doi:10.1038/ $335714 \mathrm{a} 0$

Bauer J, Kuss J, Steuber T (2003) Sequence architecture and carbonate platform configuration (Late Cenomanian-Santonian), Sinai, Egypt. Sedimentology 50:387-414. doi:10.1046/j.13653091.2003.00549.x

Bauer J, Marzouk AM, Steuber T, Kuss J (2001) Lithostratigraphy and biostratigraphy of the Cenomanian-Santonian strata of Sinai, Egypt. Cretac Res 22:497-526. doi:10.1006/cres.2001. 0270

Bodin S, Godet A, Follmi KB, Vermeulen J, Arnaud H, Strasser A et al (2006) The late Hauterivian Faraoni oceanic event in the western Tethys: evidence from phosphorus burial rates. Palaeogeogr Palaeoclimatol Palaeoecol 235:238-257. doi:10.1016/ j.palaeo.2005.09.030

Chancellor GR, Kennedy WJ, Hancock JM (1994) Turonian ammonite faunas from Central Tunisia. Spec Pap Paleontol 50:1-118

Chamley H (1989) Clay sedimentology. Sringer, Heidelberg, 623 p

Cherief OH, Al Rifaiy IA, Al Afify FI, Orabi OH (1989) Foraminiferal biostratigraphy and paleoecology of some CenomanianTuronian exposures in west central Sinai (Egypt). Rev Micropaleontol 31:243-262

Cobban WA, Scott RW (1972) Stratigraphy and ammonite fauna of the graneros shale and greenhorn limestone near Pueblo, Colorado, Washington DC. US Geol Surv Prof Pap 645:1-108
Corliss BH, Chen C (1988) Morphotype patterns of Norwegian Sea deep-sea benthic foraminifera and ecological implications. Geology 16:716-719. doi:10.1130/0091-7613(1988)016<0716: MPONSD $>2.3 . \mathrm{CO} ; 2$

Davey SD, Jenkyns HC (1999) Carbon-isotope stratigraphy of shallow-water limestones and implications for the timing of Late Cretaceous sea-level rise and anoxic events (CenomanianTuronian of the peri-Adriatic carbonate platform, Croatia). Eclogae Geol Helv 92:163-170

Dhondt AV, Malchus N, Boumaza L, Jaillard E (1999) Cretaceous oysters from North Africa: origin and distribution. Bull Soc Geol Fr 170(1):67-76

Douglas RG, Savin SM (1978) Oxygen isotopic evidence for depth stratification of tertiary and Cretaceous planktic foraminifera. Mar Micropaleontol 3:175-196. doi:10.1016/0377-8398(78) 90004-X

Eicher DL, Worstell P (1970) Cenomanian and Turonian foraminifera from the Great Plain, United States. Micropaleontol 16:269-324. doi: $10.2307 / 1485079$

Elder WP (1985) Biotic pattern across the Cenomanian-Turonian extinction boundary near Pueblo, Colorado. Pratt LA, Kauffman EG, Zelt FB (eds) Fine grained deposits and biofacies of the Cretaceous Western interior seaway: evidence of cyclic sedimentary processes. Field Trip Guidebook, vol 4. Society of Economic Paleontologists and Mineralogists, Tulsa, pp 157-169

El-Hedeny MM (2002) Cenomanian-Coniacian ammonites from west-central Sinai, Egypt, and their significance in biostratigraphy. N Jb Geol Palont Mh 7:397-425

El-Sabbagh AM (2000) Stratigraphical and paleontological studies of the Upper Cretaceous succession in Gebel Nezzazat and Bir ElMarkha areas, West-Central Sinai, Egypt. Unpublished PhD Thesis, Alexandria University, Fac Sci, Geol Dept: 209 p

Erba E, Tremolada F (2004) Nannofossil carbonate fluxes during the Early Cretaceous: phytoplankton response to nutrification episodes, atmospheric $\mathrm{CO}_{2}$, and anoxia. Paleoceanography 19:1-18. doi:10.1029/2003PA000884

Erbacher J, Thurow J, Littke R (1996) Evolution patterns of radiolaria and organic matter variations: a new approach to identify sealevel changes in mid-Cretaceous pelagic environments. Geology 24:499-502. doi:10.1130/0091-7613(1996)024<0499:EPORAO> 2.3.CO; 2

Gale AS, Hardenbohl J, Hathway B, Kennedy WJ, Young JR, Phansalkar V (2002) Global correlation of cenomanian (upper Cretaceous) sequences: evidence for Milankovitch control on sea level. Geology 30:291-294. doi:10.1130/0091-7613(2002)030 $<0291$ :GCOCUC $>2.0 . \mathrm{CO} ; 2$

Gertsch B, Keller G, Adatte T, Berner Z, Stueben D, Tantawy AAAM, El-Sabbagh, AM (2008) Middle and late Cenomanian Anoxia in the shallow shelf environment in NW Morocco (in preparation)

Ghorab MA (1961) Abnormal stratigraphic features in Ras Gharib Oilfield, Egypt. Proceedings of the Third Arab Petroleum Congress, Alexandria, Egypt, pp 1-10

Godet A, Bodin S, Adatte T, Foellmi KB (2008) Clay mineral assemblages along the Northern Tethyan margin during the late Hauterivian-early Aptian: interactions beween climate change and carbonate platform evolution. Cretac Res (in press)

Hallam A (1992) Phanerozoic sea level changes. Columbia press, New York

Haq BU, Hardenbol J (1987) Chronology of fluctuating sea levels since the Triassic. Science 235:1156-1167. doi:10.1126/science. 235.4793.1156

Hart MB (1999) The evolution and biodiversity of Cretaceous planktonic Foraminiferida. Geobios 32:247-255. doi:10.1016/ S0016-6995(99)80038-2 
Hart MB (1980) A water depth model for the evolution of the planktonic foraminifera. Nature 286:252-254. doi:10.1038/ $286252 \mathrm{a} 0$

Hart MB, Leary PN (1989) The stratigraphic and paleogeographic setting of the late cenomanian anoxic event. J Geol Soc Lond 146:305-310. doi:10.1144/gsjgs.146.2.0305

Huber BT, Norris RD, McLeod KG (2002) Deep-sea paleotemperature record of extreme warmth during the Cretaceous. Geology 30:123-126. doi:10.1130/0091-7613(2002)030<0123:DSPROE $>$ 2.0.CO;2

Jarvis I, Gale AS, Jenkyns HC, Pearce MA (2006) Secular variation in late Cretaceous carbon isotopes: a new $\delta 13 \mathrm{C}$ carbonate reference curve for the Cenomanian-Campanian (99.6-70.6 Ma). Geol Mag 143:561-608. doi:10.1017/S0016756806002421

Jarvis I, Carson GA, Cooper MKE, Hart MB, Leary PN, Tocher BA et al (1988) Microfossil assemblages and the CenomanianTuronian (late Cretaceous) oceanic anoxic event. Cretac Res 9:3-103. doi:10.1016/0195-6671(88)90003-1

Jenkyns HC (1980) Cretaceous anoxic events, from continents to oceans. J Geol Soc Lond 137:171-181. doi:10.1144/gsjgs.137.2. 0171

Jenkyns HC, Gale AS, Corfield RM (1994) Carbon- and oxygenisotope stratigraphy of the English Chalk and Italian Scaglia and its palaeoclimatic significance. Geol Mag 131:1-34

Kassab AS, Obaidalla NA (2001) Integrated biostratigraphy and interregional correlation of the Cenomanian-Turonian deposits of Wadi Feiran, Sinai, Egypt. Cretac Res 22:105-114. doi:10.1006/ cres. 2000.0240

Kassab AS (1999) Cenomanian-Turonian boundary in the Gulf of Suez region, Egypt: towards an inter-regional correlation, based on ammonites. Geological Society of Egypt. Spec Publ 2:61-98

Kassab AI, Ismael MM (1996) Biostratigraphy of the upper Cretaceous sequence of the Gebel Musabaa Salama area, south-west Sinai, Egypt. Arab Gulf J Sci Res 14:63-78

Kassab AI, Ismael MM (1994) Upper Cretaceous invertebrate fossils from the area northeast of Abu Zeneima, Sinai, Egypt. Neues Jahrb Geol Palaontol Abh 191:221-249

Kassab AS (1991) Cenomanian-Coniacian biostratigraphy of the northern Eastern Desert, Egypt, based on ammonites. Newsl Stratigr 25:25-35

Kassab AS (1985) Palaeontological and stratigraphical studies of Cretaceous sections in Wadi Tarfa and Wadi Qena, Eastern Desert, Egypt. PhD Thesis, Assiut University, Assiut: 221pp

Keller G, Tantawy AA, Berner Z, Adatte T, Chellai EH, Stueben D (2008) Oceanic events and biotic effects of the CenomanianTuronian anoxic event, Tarfaya Basin, Morocco. Cretaceous Res. doi:10.1016/j.cretres.2008.05.020

Keller G, Berner Z, Adatte T, Stueben D (2004) CenomanianTuronian and delta $\mathrm{C}-13$, and delta $\mathrm{O}-18$, sea level and salinity variations at Pueblo, Colorado. Palaeogeogr Palaeoclimatol Palaeoecol 211:19-43. doi:10.1016/j.palaeo.2004.04.003

Keller G, Pardo A (2004) Age and paleoenvironment of the Cenomanian-Turonian global stratotype section and point at Pueblo, Colorado. Mar Micropaleontol 51:95-128. doi:10.1016/ j.marmicro.2003.08.004

Keller G, Han Q, Adatte T, Burns SJ (2001) Palaeoenvironment of the Cenomanian-Turonian transition at Eastbourne, England. Cretac Res 22:391-422. doi:10.1006/cres.2001.0264

Kolonic S, Wagner T, Forster A, Sinninghe Damste JS, WalsworthBell B, Erba E et al (2005) Black shale deposition on the northwest African Shelf during the Cenomanian/Turonian oceanic anoxic event: climate coupling and global organic carbon burial. Paleoceanography 20:1-18. doi:10.1029/2003PA000950

Kolonic S, Damste JSS, Bottcher ME, Kuypers MMM, Kuhnt W, Beckmann B et al (2002) Geochemical characterization of Cenomanian/Turonian black shales from the Tarfaya Basin (SW
Morocco)—relationships between palaeoenvironmental conditions and early sulphurization of sedimentary organic matter. J Pet Geol 25:325-350. doi:10.1111/j.1747-5457.2002.tb00012.x

Kora M, Shahin A, Semiet A (1994) Biostratigraphy and paleoecology of some Cenomanian successions in the west-central Sinai, Egypt. Neues Jahrb Geol Palaontol Monatsh 1994:597-617

Kora M, Hamama HH (1987) Biostratigraphy of the CenomanianTuronian successions of Gebel Gunna, southeastern Sinai, Egypt. Mansoura Faculty of Science. Bulletin 14:289-301

Koutsoukos EAM, Leary PN, Hart MB (1990) Latest Cenomanianearliest Turonian low-oxygen tolerant benthonic foraminifera: A case-study from the Sergipe basin (N.E. Brazil) and the western Anglo-Paris basin (southern England). Palaeogeogr Palaeoclimatol Palaeoecol 77:145-177. doi:10.1016/0031-0182(90) 90130-Y

Kuhnt W, Nederbragt A, Leine L (1997) Cyclicity of CenomanianTuronian organic-carbon-rich sediments in the Tarfaya Atlantic Coastal Basin (Morocco). Cretac Res 18:587-601. doi:10.1006/ cres.1997.0076

Kuhnt W, Luderer F, Nederbragt S, Thurow J, Wagner T (2004) Orbital-scale record of the late Cenomanian-Turonian oceanic anoxic event (OAE-2) in the Tarfaya Basin (Morocco). Int $\mathrm{J}$ Earth Sci 94:147-159. doi:10.1007/s00531-004-0440-5

Kübler B (1983) Dosage quantitatif des minéraux majeurs des roches sédimentaires par diffraction X. Cahiers de l'Institut de Géologie Series AX no. 1.1 and 1.2:1-13

Kübler B (1987) Cristallinité de l'illite: méthode normalisées de préparation de mesure, méthode automatique normalisées de mesure. Cahiers de l'Institut de Géologie

Kübler B, Jaboyedoff M (2000) Illite Cristallinity. CR Ac Sc Paris Sci de la terre et des planètes/Earth Planet Sci 331:75-89

Leary PN, Peryt D (1991) The Late Cenomanian oceanic anoxic event in the western Anglo-Paris Basin and southeast Danish-Polish Trough: survival strategies of and recolonization by benthonic foraminifera. Hist Boil 5:321-335

Leckie RM (1987) Paleoecology of the mid-Cretaceous planktic foraminifera: a comparison of open ocean and epicontinental sea assemblages. Micropaleontology 33:164-176. doi:10.2307/ 1485491

Leckie RM, Yuretich RF, West LOL, Finkelstein D, Schmidt M (1998) Paleoceanography of the southwestern Interior Sea during the time of the Cenomanian-Turonian boundary (late Cretaceous). Dean WE, Arthur MA (eds) Concepts in sedimentology and paleontolgy, vol 6 SEPM, USA, pp 101-126

Leckie RM, Bralower TJ, Cashman R (2002) Oceanic anoxic events and plankton evolution: Biotic response to tectonic forcing during the mid-Cretaceous. Paleoceanography 17(3). doi: 10.1029/2001PA000623

Luning S, Kolonic S, Belhadj EM, Belhadj Z, Cota L, Baric G et al (2004) Integrated depositional model for the CenomanianTuronian organic-rich strata in North Africa. Earth Sci Rev 64:51-117. doi:10.1016/S0012-8252(03)00039-4

Luning S, Marzouk AM, Morsi AM, Kuss J (1998) Sequence stratigraphy of the Upper Cretaceous of central-east Sinai, Egypt. Cretac Res 19:153-196. doi:10.1006/cres.1997.0104

Malchus N (1990) Revision der Kreide-Austern (Bivalvia: Pteriomorphia) Agyptens (Biostratigraphie, Systematik). Berliner Geowissenschaftliche Abh A125:231 p

Marshall JD (1992) Climatic and oceanographic isotopic signals from the carbonate rock record and their preservation. Geol Mag 129:143-160

Meister C, Allzuma K, Mathey B (1992) Les ammonites du Niger (Afrique occidentale) et la Transgression Transsaharienne au cours du Cenomanien-Turonien. Geobios 25:55-100

Mort HP, Adatte T, Foellmi KB, Keller G, Steinmann P, Matera V et al (2007) Phosphorus and the roles of productivity and nutrient 
recycling during oceanic event 2. Geology 35:483-486. doi: 10.1130/G23475A.1

Murray JW (1973) Deposition and ecology of living benthic foraminiferids. Russak and Co, Carne, pp 1-274

Nederbragt A, Fiorentino A (1999) Stratigraphy and paleoceanography of the Cenomanian-Turonian boundary event in Oued Mellegue, northwestern Tunisia. Cretaceous Res 20:47-62

Nield EW, Tucker VCT (1985) Paleontology. An introduction. Pergamon Press, $178 \mathrm{p}$

Norris RD, Bice KL, Magno EA, Wilson PA (2002) Jiggling the tropical thermostat in the Cretaceous hothouse. Geology 30:299302

Orabi HO (1992) Cenomanian-Turonian boundary in Whadi Watir, southeastern Sinai, Gulf of Aqaba, Egypt. J Afr Earth Sci 15:281-291

Pascal AF, Mathey BJ, Alzuma K, Lang L, Meister C (1993) Late Cenomanian-Early Turonian shelf ramp, Niger, west Africa. Simo AJ, Scott RW, Masse JP (eds) Cretaceous carbonate platforms. Am Assoc Pet Geol Bull Memoir 56:145-154

Paul CRC, Lamolda MA, Mitchell SF, Vaziri MR, Gorostidi A, Marshall JD (1999) The Cenomanian-Turonian boundary at Eastbourne (Sussex, UK): a proposed European reference section. Paleogeogr Paleoclimatol Paleoecol 150:83-121

Paul CRC, Mitchell SF, Marshall JD, Leary PN, Gale AS, Duane AM, Ditchfield PW (1994) Palaeoceanographic events in the middle Cenomanian of Northwest Europe. Cretaceous Res 15:707-738

Perty D, Lamolda M (1996) Benthonic foraminiferal mass extinction and survival assemblages from the Cenomanian-Turonian boundary event in the Menoyo section, northern Spain. Hart M (ed) Biotic recovery from mass extinction events. Geol Soc Special Publ 102:245-258

Petters SW (1980) Foraminiferal paleoecology of Nigerian late Cretaceous epeiric seas. Ann Mus Hist Nat 6:82-133

Philip J (2003) Peri-Tethyan neritic carbonate areas: distribution through time and driving factors. Paleogeogr Paleoclimatol Paleoecol 196:19-37
Philip JM, Airaud-Crumiere C (1991) The demise of the rudistbearing carbonate platforms at the Cenomanian/Turonian boundary: a global control. Coral Reefs 10:115-125

Price GD, Hart MB (2002) Isotopic evidence for early to midCretaceous ocean temperature variability. Mar Micropaleontol 46:45-58

Pufahl PK, James NP (2006) Monospecific Pliocene oyster buildups, Murray Basin, South Australia: brackish water end member of the reef spectrum. Paleogeogr Paleoclimatol Paleoecol 233:11-33

Robaszynski F, Gale AS (1993) The Cenomanian-Turonian boundary: a discussion held at the final session of the colloquium on the Cenomanian-Turonian events, Grenoble, 26th May 1991 (France). Cretaceous Res 14:607-611

Sageman BB, Meyers SR, Arthur MA (2006) Orbital time scale and new $\mathrm{C}$-isotope record for Cenomanian-Turonian boundary stratotype. Geology 34(2):125-128

Schrag DP, DePaolo DJ, Richter FM (1995) Reconstructing past sea surface temperatures: correcting for diagenesis of bulk marine carbonate. Geochem Cosmochim Acta 59:2265-2278

Schulze F, Kuss J, Marzouk A (2005) Platform configuration, microfacies and cyclicities of the upper Albian to Turonian of west-central Jordan. Facies 50:505-527

Schulze F, Marzouk AM, Bassiouni MAA, Kuss J (2004) The late Albian-Turonian carbonate platform succession of west-central Jordan: stratigraphy and crisis. Cretaceous Res 25:709-737

Schulze F, Lewy Z, Kuss J, Gharaibeh A (2003) CenomanianTuronian carbonate platform deposits in west central Jordan. Int J Earth Sci (Geol Rundsch) 92:641-660

Tsikos H, Jenkyns HC, Walsworth-Bell B, Petrizzo MR, Forster A, Kolonic S, Erba E, Premoli Silva I, Baas M, Wagner T, Sinninghe Damste JS (2004) Carbon-isotope stratigraphy recorded by the Cenomanian-Turonian oceanic anoxic event: correlation and implications based on three key localities. J Geol Soc 161:711-719 